PARRY, Manon Sian. Public health heritage and policy: HIV and AIDS in museums and archives. História, Ciências, Saúde - Manguinhos, Rio de Janeiro, v.27, supl., set. 2020, p.253-262.

\title{
Public health heritage and policy: HIV and AIDS in museums and archives
}

\section{Herança e política de saúde pública: HIV e aids em museus e arquivos}

\author{
Manon Sian Parry ${ }^{i}$ \\ University of Amsterdam; Vrije Universiteit Amsterdam. \\ Amsterdam - Netherlands \\ orcid.org/0000-0001-8369-2708 \\ m.s.parry@uva.nl
}

Abstract

In the last five years there has been a resurgence of scholarly research and museum exhibitions on the history of HIV and AIDS. This work has called into question some of the conventions of archiving and interpreting the history of the pandemic. It is increasingly clear that a narrow range of materials have been saved. As historians and curators turn to these holdings for analysis and exhibition, they find they inadequately represent the impact of AIDS across diverse groups as well as the range of local, national, international responses. This essay considers some of the factors that shape collection of the material culture, particularly the heritage of public health, and the consequences for our understanding of lessons from the past.

Keywords: AIDS; museums; collections; public history; HIV.

Resumo

Nos últimos cinco anos, retomaram-se as pesquisas acadêmicas e exposições museológicas sobre a história do HIV e da aids. Este trabalho questiona algumas das convenções de arquivamento e interpretação da história da pandemia. Fica cada vez mais claro que foi preservada uma pequena amostra de materiais. À medida que historiadores e curadores recorrem a esse patrimônio para análise e exposição, descobrem que representam de maneira inadequada o impacto da aids em diversos grupos, bem como o escopo das respostas locais, nacionais e internacionais. Este artigo considera alguns dos fatores que influenciam a coleção de cultura material, em particular o legado da saúde pública e as consequências de nossa compreensão das lições do passado.

Palavras-chave: aids; museus; coleções; história pública; HIV. 
$\mathrm{W}$ hile academics and public health practitioners continue to debate the relevance of history for practice and policy (Szreter, 2011; Green, 2016; Berridge, 2018), historical interpretations, whether carefully constructed or problematically framed and flawed, are already put to use in the management of health and illness. Although not always part of a conscious instrumentalisation of the past, legacies, lessons, and myths shape healthcare, from the attitudes of patients to the assumptions of healthcare professionals and policymakers. Yet as Hooman Momen (2018), WHO staff member, noted in his presentation at a Geneva workshop on "The Meaning(s) of Global Public Health: Scholarly and Policy Implications," global health histories can be "highly subjective... strongly influenced both by the interpretations of the historians and their cultural and social background as well as the selective reading of history by public health officials."

HIV and AIDS provide an instructive example. In fact, as we approach the fortieth anniversary of its emergence, the history of the pandemic appears to be in crisis. While there has been a swell of new scholarship (Geary, 2014; Woubshet, 2015; France, 2016; Tsampiras, 2020), this surge of activity has drawn attention to exclusions, misrepresentations, and misunderstandings of the historical record. Archives have saved only a narrow range of documentation, even though those affected and involved in the response seemed aware of the historical significance of this new disease from the outset (Harden, 2012, chapter 6). In museum collections, the three main types of surviving material - art, activist ephemera, and public health media - represent only some groups, and reflect a limited array of activities. Historians and curators have found the collections inadequate for analysis and exhibition, as they fail to represent the full impact of HIV and AIDS across diverse groups, as well as the broad scope of local, national, international action (Kerr, Aug. 2019; Parry, Schalkwijk, 2020).

For example, while the art of white gay men is frequently displayed, artists outside of the so-called "AIDS canon" are excluded (Kerr, 31 Dec. 2015), prompting public protests at the Tacoma Art Museum in 2015, where activists staged a series of "die-ins" to draw attention to the underrepresentation of black artists in the exhibition Art, AIDS, America (Colucci, 16 June 2017). The controversy arose from the "whitewashing" of the history of AIDS in the USA, not only because of the higher burden of HIV infection among black Americans now, but also due to recent research demonstrating that epidemiologists excluded cases among this group from their very first reports (Kerr, 2016; Moseby, 2017, p.1068).

All of this is problematic not only because archives and museum collections fuel inaccurate perceptions of the past, but also because these histories feed into the trajectory of disease in the present. Historian Richard McKay (2017), for example, has brilliantly demonstrated how deliberate exaggeration by journalist Randy Shilts merged popular fantasies and public health practices to create the myth of Gaetan Dugas, the so-called patient zero blamed for bringing HIV to the USA. The result was the demonisation of one man, a Canadian air steward, as the link between clusters of many cases. This myth then travelled the globe in widely-circulated media, contributing to stigmatising representations of gay male sexuality as well as the criminalisation of HIV transmission in numerous countries (McKay, 2014, p.187-191). 
McKay reconstructed the process by which the shorthand of public health professionals, who were reading the "O" for "Out of California" as "zero" in their discussions of clusters of cases, came to stand for the origins of the American epidemic. By building trust among surviving friends and family, McKay was able to ascertain more details of Dugas's life before and after diagnosis, creating a new archive of oral histories which contradict the narrative launched by Shilts (McKay, 2017, p.31-37). The legacy of misrepresentation still endures, informing anxieties about deliberate contagion that are increasingly used to prosecute already marginalised people (McKay, 2014, p.165; Hoppe, 2017). History is used in global public health then, even if it is inaccurate.

The question I raise here is what if the failure to learn from global health histories in general, and the history of AIDS specifically, is not only due to subjectivity or selectivity, as Momen and others suggest, but also from the failure to adequately collect, preserve, and make accessible the traces of this past? In the analysis that follows, I discuss the preservation and reuse of AIDS education materials in archives and museums, and the implications for investigating and interpreting the global history of the pandemic. I argue that projects based on this heritage of public health provide a partial, and often problematic view of this past.

Public health collections have received far less scholarly analysis than artworks or activist materials (Parry, 2019), with most focusing on the messages and assumptions embedded within, rather than their afterlife in the new histories created by collectors, curators, and audiences. Yet these materials are frequently reused, and may be especially influential in the realms of public health practice and policy, where they might be perceived as more scientific, professional, or relevant than the art or activist work that also dominates the material culture of HIV and AIDS in museums and archives.

Indeed explicit attempts are being made to use the history of HIV and AIDS to inform health policy, such as a recent Rockefeller Archive Center meeting on the value of the archives for informing the use of philanthropic funding (Royles, 2017), or historical epidemiological analyses intended to inform the UNAIDS 90-90-90 campaign to "help end the AIDS epidemic" (Kazanjian, 2017). Where some have concluded that history may be inadequate to inform health policy, I suggest here that it is heritage: the evidence and artifacts saved and stored, that may actually undermine the power of the past, especially if we collect too little, and too late.

\section{Collecting and exhibiting the paraphernalia of public health}

Perhaps the most ubiquitous "things" generated by the pandemic and collected in archives and museums are the materials associated with HIV education. Although designed only for short-term use, and thus labelled as "ephemera," in fact posters, leaflets, postcards, and badges are the predominant cultural traces of AIDS that have been professionally preserved (Cooter, Stein, 2007). Multiple copies of mass-produced campaign posters and flyers were created, and therefore many examples have survived - proving especially resilient in comparison to more personal items, which are sometimes destroyed in grief, or kept privately as a link to someone lost to AIDS rather than donated to a museum or 
archive (Harden, 1995, p.164). Collections include a wide variety of types, from the glossy mass-produced media of national government-led campaigns, to the smaller-scale output of artists and community groups working with more limited resources.

Another influential factor in their survival is the ease with which two-dimensional paper and card can be stored, especially compared to the challenges of caring for some of the other material traces of HIV and AIDS. The NAMES Quilt, for example, the world's largest folk art project, is made up of thousands of textile panels created to commemorate individuals who have died of AIDS. Preservation is costly because of its size as well as the complexities of preserving and restoring so many different kinds of handcrafted objects made up of a wide variety of elements (Meijer-van Mensch, de Wildt, 2014).

All of these factors also shape the reuse of the material culture of the history of HIV and AIDS. Posters have been especially widely presented in publications as well as exhibition projects, illustrating the range of creative, witty, startling, or subversive approaches used all around the world (Rigby, Leibtag, 1994; Döring, 1996; Museum für Gestaltung Zürich, 2002; Resnick, 2010). They are easier to exhibit than three-dimensional objects, and copies and originals with many duplicates can be shown in a range of settings without the need for temperature-controlled exhibition cases, expensive insurance, or specialised transportation. Temporary exhibitions such as those marking World AIDS Day on the first of December often draw on existing materials in an institution's collection precisely because they can be quickly developed based on these holdings, using the real artifacts or reproductions of them. It is also common to see copies displayed in public spaces (on the streets, public transportation, and city government buildings), with an educational message about HIV awareness, and usually very minimal interpretation or historical analysis. Due to the ease with which they can be digitised, plenty of examples are available for use online, or to download.

The sheer variety available makes it possible to exhibit the broad reach of the global pandemic, representing diverse communities and countries. However, these materials give only a shallow sense of the place of a specific media campaign within a wider range of activities and issues, not to mention the gap between the expected and actual impact, or how audiences reacted to these efforts. Generally, these projects do not provide information about the circumstances of the production of the campaigns, a limitation common to much media history as background documentation has not usually been preserved. There is even less attention to the reception of these materials in the diversity of settings in which they were used, from city centres to rural locations, adult-only venues to public hoardings or schools. Without much information or explanation of these dimensions, then, public health promotion is often instead presented as visual art.

The recent exhibition AIDS - Based on a True Story drew on a collection of 10,000 AIDS posters from 147 countries housed at the German Museum of Hygiene in Dresden, intermingled with art and activist material that reflected changing iconography in the visual culture of HIV and AIDS. The exhibition was displayed in Dresden from 2015 to 2016, and subsequently shown at the International Museum of the Red Cross, Geneva, from 2017 to 2018. Curator Vladimir (Ĉajkovac, 2015, p.19) attempted to go beyond an aesthetic framework, explaining that his selection prioritised "those posters that have 
led to misunderstandings, controversies and ruptures in social, religious, and scientific concepts of morality, sexuality, and intimacy." Even so, the project highlights some of the key challenges of relying on these compelling visuals to convey the complex history of HIV across its social, cultural, and political dimensions.

The exhibition consisted of six rooms, with each organised by a theme that united the range of posters displayed therein, such as "The Virus" or "Living Together." The rooms moved forward in time in a loose chronology implicitly tied to phases of scientific discovery, including the identification of the HIV virus through to the development of effective medical treatments, as the posters shift in emphasis from warning of a deadly disease to depicting people living with HIV. The exhibition also included a timeline reinforcing this narrative arc, criticised by some cultural scholars for using "broad strokes to build a linear narrative" of increasing knowledge and better management of the threat (Köppert, Sekuler, 2016, n.p.).

Such "progress" narratives are common to AIDS exhibitions, especially those on specific anniversaries or World AIDS Day, because they are stimulated by the passage of time since the first cases of HIV were noted. Even without explicit reference to a timeline, by contrasting the death toll of the early years and varying rates of infection in different regions or moments, such projects commonly suggest a beginning, and anticipate an end, for the global pandemic. The march forward has become so ubiquitous in AIDS memory that challenging the complacency it has produced is now a central part of activism and policy: the expression "AIDS is not over" featured in the Dresden exhibition catalogue in 2015, was promoted as the core message of the International AIDS Society meeting in Amsterdam in 2018, and serves as the title of a forthcoming special issue of Radical History Review due in 2021 on the pandemic.

The juxtaposition of posters from different countries, in print, online or in gallery exhibition projects, suggests that you can trace cultural differences between them. Indeed, you can see interesting differences in approaches to sexuality, as well as contrasts between official public health campaigns and those developed by advocacy organisations. However, these comparisons can be misleading. For example, the graphic and direct style of Dutch posters aimed at gay men, combined with a general view of the Netherlands as especially "tolerant" of homosexuality, suggest a particularly open approach when compared to some other countries. The predominant history of AIDS concludes that, indeed, there was a successful and effective collaboration between gay activists and government leaders from the very outset of the epidemic there (Mooij, 2004). Historians and sociologists there have argued, however, that Dutch queer activism has been depoliticised by this close cooperation between government officials and elite community leaders, who coalesced around values that were not shared by others across the diverse gay community (Hekma, Duyvendak, 1996). This led to conservative policymaking, with no sex rather than safe sex as the core educational message of government-sponsored campaigns (de Zwart, Sandfort, van Kerkhof, 1998).

The Dutch response is certainly starkly different to the more infamous imagery of tombstones and icebergs used in the first national campaign in the United Kingdom. This latter project was featured in the Wellcome Collection exhibition in London in 2017, Can 
Graphic Design Save Your Life? This exhibition, curated by designer Lucienne Roberts and design educator Rebecca Wright, delivered a mostly celebratory storyline which implied that indeed, it can (Schrauwen, Roberts, Wright, 2017). While the curators addressed the use of design to sell unhealthy behaviours such as smoking (through tobacco advertising), overall the exhibition highlighted the power of imagery to persuade people to take actions for their own good and for wider public health (Wainwright, 17 Sept. 2017).

The AIDS Monolith advert and campaign, informally known as the "Don't Die of Ignorance" project after the main tagline of the television spots and print materials, was featured, alongside a brief label noting that the campaign was controversial but highly memorable. A Guardian article promoting the opening of the exhibition featured edited interviews with Norman Fowler, the government minister for Health at the time of the campaign, and one of the designers, reflecting on its history (Jonze, 4 Sept. 2017). Both commented upon the difficulty of the project in the face of intense opposition, and asserted that their approach was necessary and successful. There was no discussion or analysis of these remarks by the journalist credited for the article, nor any other contextualising information provided. Yet as historians have pointed out, such accounts drastically limit the interpretive framework for understanding the goals of this campaign and ignore the uneven evidence of its impact (Kelly, Barker, July 2016; Kershaw, 20 May 2018).

By isolating this communication effort from the wider variety of activities underway at the time, such historical narratives suppress the role of other campaigns and services, like those provided by the Terrence Higgins Trust, and ignore the influence of amplifying or competing representations of AIDS in the media and wider culture. While some researchers conclude that the campaign may have been effective in raising awareness, there is less evidence for increased condom use, especially among the heterosexual population. Moreover, the impact was likely to have been short-term, as sustained behaviour change requires longer-term efforts not only in education but also in empowerment. The campaign may actually have proven more long-lasting in terms of the fear and stigma it generated (National Aids Trust, 2016, p.12).

Thirty years later, historians, public health practitioners, and policy makers still disagree on its impact. Notorious for its use of fear, the campaign has been criticised for terrifying general audiences, potentially prejudicing them against those groups most at risk, and for serving as a public relations exercise for the government rather than a serious public health effort aimed at saving lives (Graham, 2013). Yet the politicians and graphic designers involved now claim it as an unqualified success (Jonze, 4 Sept. 2017), and despite numerous scientific studies questioning the impact of fear-based health communication, the strategy is making a comeback in the field of public health - for many health issues and well beyond the borders of the UK (Fairchild et al., 2018). This revival is particularly worrying in the current climate of distrust of expertise and the spread of fake (health) news, as it seems dangerously counterproductive, potentially eroding the already fragile credibility of public health authorities.

Moreover, an overemphasis on the visual culture of health communication distracts us from one of the most important lessons of the spread of HIV, the "social determinants of 
health," which indicate that knowing how to protect oneself from infection is not enough. Economics, inequality in sexual relationships, social marginalisation, mental health and addiction issues, poor nutrition, low levels of education, lack of access to services or a safe place to live, all contribute to the risk factors for contracting the virus, as well as the impact this will have on an individual's health and wellbeing (Dean, Fenton, 2010; Edwards, Collins, 2014).

\section{Final considerations}

Capturing all of these dimensions in a collection of objects, images, and documents presents a significant challenge for archives and museums. My research has highlighted significant problems in the management of the material culture of the pandemic. Taking the Netherlands, where I am currently based, as an example, I can identify three main issues. Firstly, collections policies place limits on the kinds of objects that qualify for museum accession, and many are inadequate for addressing HIV and AIDS. The Rijksmuseum Boerhaave, for example, is the national museum for the history of science and medicine, and until 2020, did not own a single object related to the topic - on the grounds that curators had not been able to identify one that fit with the collection's focus on scientific innovation (Parry, Schalkwijk, 2020). After a witness seminar with medical staff and people living with HIV in 2018 failed to generate enthusiasm for any materials discussed there, the museum has begun to consider an expanded definition that would allow for the inclusion of a piece of the Dutch AIDS quilt.

Secondly, medical heritage (or material produced in medical settings) is vulnerable if it is not considered valuable for contemporary practice. A scrapbook of photographs and notes from staff, patients, and visitors in one of the country's first AIDS wards, as well as the original handwritten guide to caring for someone with AIDS produced by a team of carers involved in introducing the Buddy system to the Netherlands, have both been lost - although a typed copy of the guide has been found, it still remains in the personal collection of an individual rather than a formal archive (Parry, Schalkwijk, 2020).

Thirdly, museums replicate the silences and erasures of the societies they document, with groups on the margins, such as intravenous drug users and sex workers, underrepresented. At a 2018 workshop at the Amsterdam Museum to discuss AIDS collecting, participants discussed a needle-dispensing machine from the holdings of the Science Museum as a possible object that could be sought out in Amsterdam, given the city's history as a centre for heroin use in the 1980s and status as the first country in the world to introduce needle exchange programmes, in 1984 (Strathdee, Vlahov, 2001). We wondered, however, whether such a machine was used - assuming instead that a better-funded environment might have meant that staff were used for this role rather than technologies. A photograph from an exhibition at the Amsterdam City Archives that year confirmed that such a machine had been used, although a surviving example has not yet been located. Collecting more personal items from individuals, rather than public health institutions or initiatives, would require a longer process of collaboration with people who may not be in a position to prioritise such a search for heritage. 
In an attempt to diversify the viewpoints saved and shared, a number of major archival projects have been undertaken which focus on oral histories rather than objects as a means to preserve these pasts. These include "The Face of AIDS" film archive at the Karolinska Institutet in Stockholm, which houses 700 hours of edited and unedited film footage from every continent except Antarctica, recorded by Swedish film director and journalist Staffan Hildebrand between 1987 and 2017 (Björklund, Larsson, 2018, p.XIV), and the European HIV/AIDS Archive at Germany's Humboldt University, which has been open to researchers since September 2019. This collection is made up of more recent material, beginning with interviews produced for an EU-funded research project from 2016-2019 (EUROPACH) focusing on the UK, Turkey, Poland, and Germany.

Although both of these film collections were gathered for different purposes, it is likely that they could be mined for a wide range of details to contexualise the object-based collections I have discussed here. They offer opportunities, for example, to "talk back" to the material culture of health promotion, providing insights on the reception of images and ideas, as well as how these campaigns are remembered, and not just by those who made them. They might also generate new ideas for historically significant objects that should be sought out and saved, assuming they have survived.

Film archives could never become a replacement for historical artifacts, however. Many people are not willing to be filmed, and not just those from the most stigmatised or at-risk groups, as I discovered during a documentary project to interview people living with HIV in the Netherlands in 2018. Aside from general discomfort in front of a camera, stigma was also a major factor deterring people from participating. Furthermore, there are difficulties securing funding for the creation and management of film collections. Archives and museums already struggle for the staff and space needed to process and store paper and object collections, and multimedia presents additional challenges. It is more expensive to care for such collections as they degrade. The technologies needed to play them become unreliable as they age, and the media needs to be transferred, from outdated video to digital formats, for example. Researching audiovisual collections takes longer than scanning through text-based sources such as archival documents or digitised newspaper collections, simply in terms of the time needed to watch or listen to the files. Reusing media in museums is also expensive, relying on technology that may break down and presenting problems in crowded spaces as sound leaks from one area into another.

It is clear that we need to collect a more diverse range of materials then, to ensure that the many facets of the pandemic can be understood from a broad variety of perspectives. Archivists and curators institutionalise remembering, and forgetting, by accessioning objects and transforming them into heritage. This shapes the understandings we can glean from the traces of the past, as well as the lessons we present to broad audiences, including public health practitioners and policymakers. As I hope I have demonstrated here, it is critical that collections of public health heritage be expanded and interlinked with others to give a broader picture of the past and the possibilities for the future. In the meantime, important artifacts we could learn from remain at risk of loss or destruction, if they have not already disappeared. 


\section{REFERENCES}

BERRIDGE, Virginia.

Why policy needs history (and historians). Health Economics Policy and Law, v.13, n.3-4, p.1-13. 2018.

BJÖRKLUND, Elisabet; LARSSON, Mariah. $A$ visual history of HIV/AIDS: exploring the face of AIDS film archive. London: Routledge. 2018.

ĈAJKOVAC, Vladimir (Ed.).

AIDS: Based On A True Story. Trans. by Stephen Grynwasser. Dresden: Verlag des Deutschen Hygiene-Museums. 2015.

COLUCCI, Emily.

Honoring communities of care in "AIDS At Home" at museum of the city of New York. Filthy Dreams [blog]. Available at: <https:// filthydreams.org/2017/06/16/honoringcommunities-of-care-in-aids-at-home-atmuseum-of-the-city-of-new-york/>. Access on: 1 July 2019. 16 June 2017.

COOTER, Roger; STEIN, Claudia. Coming into focus: posters, power, and visual culture in the history of medicine. Medizinhistorisches Journal 42, p.180-209. 2007.

DE ZWART, Onno; SANDFORT, Theo; VAN KERKHOF, Marty.

No anal sex please: we're Dutch. A dilemma in HIV prevention directed at gay men. In: Sandfort, Theo (Ed.). The Dutch response to HIV: pragmatism and consensus. London: Routledge. 1998.

DEAN, Hazel D.; FENTON, Kevin A. Addressing social determinants of health in the prevention and control of HIV/AIDS, viral hepatitis, sexually transmitted infections, and tuberculosis. Public Health Reports, v.125, suppl.4, p.1-5. 2010.

DÖRING, Jürgen (Ed.).

Gefühlsecht: graphikdesign der 90er jahre. Hamburg: Museum für Kunst und Gewerbe. 1996.

EDWARDS, Arlene E.; COLLINS JR., Charles B. Exploring the influence of social determinants on HIV risk behaviors and the potential application of structural interventions to prevent HIV in women. Journal of Health Disparities Research and Practice, v.7, special issue 2, p.141-155. 2014.

FAIRCHILD, Amy Lauren et al.

The two faces of fear: a history of hard-hitting public health campaigns against tobacco and AIDS. American Journal of Public Health, v.108, n.9, p.1180-1186. 2018.

FRANCE, David.

How to survive a plague: the inside story of how citizens and science tamed AIDS. New York: Knopf. 2016.
GEARY, Adam M.

Antiblack racism and the AIDS epidemic: state intimacies. New York: Palgrave Macmillan. 2014.

GRAHAM, Sarah.

Don't Die of Ignorance AIDS campaign:

Interview with Dr Sarah Graham. Available at: <https://www.youtube.com/watch?v=OjW_ olEfNMw>. Access on: 14 Dec. 2016. 2013.

GREEN, Alix.

History, policy and public purpose: historians and historical thinking in government. London: Palgrave Macmillan. 2016.

HARDEN, Victoria A.

AIDS at 30: a history. Washington, DC: Potomac Books. 2012.

HARDEN, Victoria A.

AIDS/Brooklyn; AIDS' human faces. Journal of American History, v.82, n.1, p.164-168. 1995.

HEKMA, Gert; DUYVENDAK, Jan Willem.

The Netherlands, depoliticization of homosexuality and homosexualisation of politics. In: Seidman, Steven (Ed.). Queer theory/ sociology. Malden, MA: Blackwell. 1996.

HOPPE, Trevor.

Punishing disease: HIV and the criminalization of sickness. Oakland: University of California Press. 2017.

JONZE, Tim.

'It was a life-and-death situation. Wards were full of young men dying': How we made the Don't Die of Ignorance Aids campaign. The Guardian. Available at: <https://www. theguardian.com/culture/2017/sep/04/how-wemade-dont-die-of-ignorance-aids-campaign $>$. Access on: 1 July 2019. 4 Sept. 2017.

KAZANJIAN, Powel.

UNAIDS 90-90-90 campaign to end the AIDS epidemic in historic perspective. The Milbank quarterly, v.95, n.2, p.408-439. 2017.

KELLY, Michael P.; BARKER, Mary.

Why is changing health-related behaviour so difficult? Public Health, v.136, p.109-116. July 2016.

KERR, Theodore (Ed.).

What you don't know about AIDS could fill a museum. [Special issue of] On Curating, n.42. Aug. 2019.

KERR, Theodore.

AIDS 1969: HIV, history, and race. Drain Magazine, v.13, n.2, (AIDS and Memory). Available at: $<$ http://drainmag.com/aids-1969-hiv-history-andrace/>. Access on: 1 July 2019. 2016. 
KERR, Theodore.

A history of erasing black artists and bodies from the AIDS conversation. Hyperallergic. Avaiable at: <https://hyperallergic.com/264934/ a-history-of-erasing-black-artists-and-bodiesfrom-the-aids-conversation/>. Access on: 1 July 2019. 31 Dec. 2015.

KERSHAW, Hannah.

Remembering and thinking critically about the 'Don't Die of Ignorance' campaign. Available at: <http://placingthepublic.lshtm. ac.uk/2018/05/20/remembering-the-dont-dieof-ignorance-campaign/>. Access on: 1 July 2019. 20 May 2018.

KÖPPERT, Katrin; SEKULER, Todd.

Sick memory: on the un-detectable in archiving Aids. Drain, v.13, n.2. Available at:<http:// drainmag.com/sick-memory-on-the-undetectable-in-archiving-aids/>. Access on: 21 July 2020. 2016.

MCKAY, Richard.

Patient zero and the making of the AIDS epidemic. Chicago: University of Chicago Press. 2017.

MCKAY, Richard.

'Patient Zero': the absence of a patient's view of the early North American AIDS epidemic. Bulletin of the History of Medicine, v.88, n.1, p.161194. 2014.

MEIJER-VAN MENSCH, Léontine; DE WILDT, Annemarie.

AIDS memorial quilts: from mourning and activism to heritage objects. In: Elpers, Sophie; Palm, Anna (Ed.). Die Musealisierung der Gegenwart. Von Grenzen und Chancen des Sammelns in Kulturhistorischen Museen. Bielefield: Verlag. p.63-82. 2014.

MOMEN, Hooman.

Reflections on a decade of Global Health History seminars at the World Health Organization and relevance to global public health. Paper presented at The Meaning(s) of Global Public Health: Scholarly and Policy Implications workshop, Brocher Foundation, 28-30

November 2018. Hermance. 2018

MOOIJ, Annet.

Geen paniek! Aids in Nederland 1982-2004.

Amsterdam: Bert Bakker. 2004.

MOSEBY, Kevin.

Two regimes of HIV/AIDS: the MMWR and the socio-political construction of HIV/AIDS as a 'black disease'. Sociology of Health and Illness, v.39, n.7, p.1068-1082. 2017.

MUSEUM FÜR GESTALTUNG ZÜRICH (Ed.). Visuelle strategien gegen AIDS / Visual strategies against AIDS. Zurich: Lars Müller Publishers. 2002.
NATIONAL AIDS TRUST.

HIV stigma: What works? Using the global evidence base to reduce the impact of HIV stigma. London: National AIDS Trust. 2016.

PARRY, Manon S.

AIDS and the Medical Museum Gaze: collecting and exhibiting science and society. On Curating, n.42, p.219-231. 2019.

PARRY, Manon S.; SCHALKWIJK, Hugo.

Lost objects and missing histories: HIV/AIDS in the Netherlands. In: Adair, Joshua G.; Levin, Amy K. (Ed.). Activism, unruliness, and alterity: gender, sexuality and museums. v.2. London: Routledge. p.113-126. 2020.

RESNICK, Elizabeth.

Graphic intervention: international AIDS awareness posters 1985-2010. Boston:

Massachusetts College of Art and Design. 2010.

RIGBY, Hugh; LEIBTAG, Susan.

HardWare: the art of prevention. Edmonton: Quon Editions. 1994.

ROYLES, Dan.

New histories of an epidemic. In: HIV/AIDS

History Collaboratory Meeting Report. Sleepy

Hollow, NY: Rockefeller Archive Center. 2017.

SCHRAUWEN, Sarah; ROBERTS, Lucienne; WRIGHT Rebecca .

Can graphic design save your life? London: Central Books. 2017.

STRATHDEE, Stephanie A.; VLAHOV, David. The effectiveness of needle exchange programs: a review of the science and policy. AIDScience. v.1, n.1, p.1-31. 2001.

SZRETER, Simon.

History, historians and development policy: a necessary dialogue. Manchester: Manchester University Press. 2011.

TSAMPIRAS, Carla.

Temporal dissonance: South African historians and the post-AIDS dilemma. Journal of Medical Humanities, v.41, n.2, p.153-169. 2020.

WAINWRIGHT, Oliver.

Can Graphic Design Save Your Life? review - thrills, pills and big pharma. The Guardian. Available at: <https://www.theguardian.com/ artanddesign/2017/sep/07/can-graphic-designsave-your-life-review-wellcome-collectionlondon>. Access on: 1 July 2019. 17 Sept. 2017.

WOUBSHET, Dagmawi.

The calendar of loss: race, sexuality, and mourning in the early era of AIDS. Baltimore: Johns Hopkins University Press. 2015. 